M.A. Thesis

\title{
Situational Situs: The Influence of Domestic Politics on Judicial Application of the Act of State Doctrine - The Russian Case
}

\author{
A. MCCOY PITT $^{*}$
}

The act of state doctrine bars courts from declaring invalid acts of foreign states occurring within that state's territory. Since its first introduction into the American legal tradition in 1867, judges, lawyers, and legal scholars have struggled to articulate a coherent interpretation of principles underlying its application. Traditional interpretations of the doctrine hold that it is governed by comity, and is thus a rule of external deference to foreign sovereigns, or that judicial application of the doctrine is driven by separation of powers concerns, and is thus a rule of internal deference to the Executive. Recognizing the shortcomings of these traditional interpretations, revisionist scholars have argued, in part, that the act of state doctrine is best understood in the context of a state's jurisdiction to prescribe. These interpretations fail to adequately describe judicial application of the act of state doctrine because they adhere solely to conventional methods of legal analysis. As a legal doctrine with foreign affairs implications, judicial application of the act of state doctrine can be explained by reference to international relations theory. A subset of liberalism, liberal internationalist theory and its model of transnational legal relations provides the framework. necessary for a holistic and coherent interpretation of the act of state doctrine. Comparisons of courts' situs determinations in intangible property cases arising from the Russian Revolution illuminates the validity of the liberal internationalist model's characterization of the doctrine. Situs in these cases serves as a proxy for each court's desire to apply or withhold application of the act of state doctrine on the basis of certain extrajudicial factors.

* J.D./M.A. Candidate, 2013, University of Virginia School of Law \& Woodrow Wilson Department of Politics. Executive Board, Virginia Journal of International Law. Captain, Phillip C. Jessup International Moot Court Team. B.B.A., International Business, 2010, University of Georgia, magna cum laude, with honors. William Crane Moore Scholar. Bebe \& Earl T. Leonard Scholar. Honors International Scholar. 
I. The Utility of International Relations Theory

for International Legal Scholarship.................................2

A. Overview of International Relations Theory \&

Its Primary Schools of Thought...............................

B. The Relationship Between International

Relations Theory \& International Law............................5

II. The Role of United States Courts in Foreign Affairs..................6

III. The Act of State Doctrine in United States Courts \&

Flaws in Its Traditional \& Revisionist Interpretations.................. 8

A. Origins \& Traditional Interpretations

of the Act of State Doctrine...................................9

B. Revisionist Interpretations of the Act of

State Doctrine .12

IV. Interpreting the Act of State Doctrine Via Liberal

International Relations Theory....................................14

A. Liberal Internationalism \& The Model of

Transnational Legal Relations.................................14

B. The Liberal Internationalist Model's Explanation

of the Act of State Doctrine...................................15

C. Usefulness of Situs to Test the Liberal

Internationalist Interpretation of the Act of State Doctrine.........17

V. The Efficacy of the Liberal Internationalist Interpretation

of the Act of State Doctrine in Russian Cases...........................18

A. Sokoloff........................................... 18

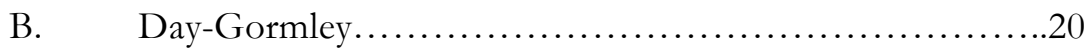

C. Belmont.........................................21

D. Review of Sokoloff, Day-Gormley, \& Belmont..............22

Concluding Remarks..............................................24

\section{THE UTILITY OF INTERNATIONAL RELATIONS THEORY FOR INTERNATIONAL LEGAL SCHOLARSHIP}

In his seminal work, How Nations Behave, the late Louis Henkin, an esteemed scholar of international law and foreign policy, remarked that as "the student of law and the student of politics ... purport to be looking at the same world from the vantage point of important disciplines ... [i] $\mathrm{t}$ seems unfortunate, indeed destructive, that they should not, at the least, hear each other."1 Henkin's words call attention to the divide between international law and international relations that persists both in academia and in practice. Scholars and practitioners of international law and international relations have, with limited exceptions, ${ }^{2}$ long embraced and perpetuated division of the two disciplines, choosing to publish in distinct

1. Louis Henkin, How NATiOns Behave: Law \& Foreign POLICY 4 (1979).

2. Francis BOYLE, WORLD POLITICS \& INTERNATIONAL LAW 59 (1985). KAPLAN \& KATZENBACH, THE POLITICAL FOUNDATIONS OF INTERNATIONAL LAW (1961). 
journals, engaging in limited cross-disciplinary discourse, and ignoring traditional methodological tools of the other. ${ }^{3}$ For example, international relations professionals maintain an aversion to positivist international law, ${ }^{4}$ and international legal professionals generally reject the utility of the major schools of international relations theory. ${ }^{5}$

International legal scholarship may be critiqued as exceedingly formalistic, neglectful of international relations theory, ${ }^{6}$ and overly reliant on international legal positivism. ${ }^{7}$ That is, international legal scholars have tended to focus narrowly on rules and institutions and have avoided employing methods of social science that might permit broader inquiry. International legal scholars persistence in this approach is detrimental to the development and synthesis of international law. Incorporation of international relations theory and other social science tools would greatly enhance international legal scholarship, expanding the scope of doctrinal analysis, refining policy prescriptions, and maximizing the explanatory power of legal theory. ${ }^{8}$

\section{A. Overview of International Relations Theory \& Its Primary Schools of Thought}

A sub-discipline within political science, international relations theory distills influences upon states into causal factors that propel, constrain, or otherwise affect state behavior. ${ }^{\text {A }}$ A successful theory explains state behavior in the international system as the outcome of causal relationships between independent and dependent variables that may then be empirically tested. ${ }^{10}$ The realist tradition of international relations theory begins with two simplifying assumptions. First, the international system is comprised of sovereign states that are the primary actors within it. ${ }^{11}$ Realism does not wholly discount the role of international institutions, multinational corporations, or other non-governmental organizations in the international system, but it does adhere to traditional Westphalian notions of statehood - that states, as sovereign, equal, and independent entities are the pinnacle of the international system. ${ }^{12}$ Second, the realist

3. Kenneth Abbott, Modern International Relations Theory: A Prospectus for International Lanyers, 14 YALE J. INT'L L. 335, 337 (1989).

4. Hedley Bull, Recapturing the Just War for Political Theory, 31 WORLD POL. 588, 588 (1979).

5. Robert Keohane, Theory of World Politics: Structural Realism and Beyond, in POLITICAL SCIENCE: THE STATE OF THE Discipline 503 (A. Finifter ed. 1983).

6. Abbott, supra note 3, at 336.

7. Boyle, supra note 2.

8. Anne-Marie Slaughter, Andrew Tulumello \& Stepan Wood, International Law \& International Relations Theory: A New Generation of Interdisciplinary Scholarship, 92 AM. J. INT’L L. 367, 373 (1998).

9. KenNeTH WALTZ, THEORY OF INTERNATIONAL POlitics 1 (1979).

10. Id. Anne-Marie Slaughter, Liberal International Relations Theory \& International Economic Law, 10 AM. INT'L L. REV. 717, 719 (1995).

11. Abbott, supra note 3 , at 346 .

12. Waltz, supra note 9, at 93-97. Robert KeOHANe, AFTER HEGEMONY: COOPERATION \& DisCORD IN THE WORLD POLITICAL ECONOMY 25 (2005). 
tradition assumes that the international system is anarchic. ${ }^{13}$ Anarchy, in this context, does not imply chaos. Rather, it means that the international system is decentralized, lacking a central enforcement authority. ${ }^{14}$ In the anarchic system "no institution, and no state, can legitimately control the action of other states by virtue of its position... [m] ore powerful states can influence weaker ones, but all are formally equal." 15

According to realist international relations theory, then, states are the primary units of the international system and are not subject to external authority absent consent. States are free to act as suits their interests and seek to maximize their relative power vis-à-vis other states because they can never be certain of other states' intentions. ${ }^{16}$ States may achieve security only by maximizing their relative power. ${ }^{17}$ These assumptions established, realism employs methods of international social choice ${ }^{18}$ and examines states as unitary rational egoists. ${ }^{19}$ States exercise strategic rationality, ${ }^{20}$ choosing a course of action after evaluating the benefits of an action relative to its costs "with reference to the potential responses of other states." 21 State behavior results from bargaining, ${ }^{22}$ coercion, ${ }^{23}$ or adaptation. ${ }^{24}$

While realists argue that states seek to maximize their relative power in the international system, conceiving of power accumulation as a zero-sum game, ${ }^{25}$ other scholars understand state interests more broadly, rejecting that power accumulation drives state behavior in all instances and asserting, instead, that states pursue dynamic interests depending upon systemic conditions. ${ }^{26}$ Institutionalism acknowledges that international organizations, rules, and customs in the international system can mediate interstate relations as they pursue their interests. ${ }^{27}$ For institutionalists, "conventions in world politics are as fundamental as the distribution of capabilities among states." 28 In other words, "institutions matter" 29

13. Abbott, supra note 3, at 347 .

14. Duncan Snidal, The Game Theory of International Politics, 38 WORLD POL. 25, 36 (1985). Arthur Stein, Coordination \& Collaboration: Regimes in an Anarchic World, 36 INT’L ORG. 299, 300 (1982).

15. Abbott, supra note 3, at 347.

16. Id. at 104. David Grann, Keenan at 90: Still in Search of Mr. X, 5 Fletcher F. WORLD AfF. 151, 151 (1994).

17. Waltz, supra note 9 , at 102 .

18. Id. at 348. Dennis Mueller, Public Choice 1-2 (1979). Oran Young, Anarchy \& Social Choice: Reflections on the International Polity, 30 WORLD POL. 241, 242-48 (1978).

19. Abbott, supra note 3, at 348.

20. Snidal, supra note 14 , at 38-40.

21. Abbott, supra note 3, at 350-351.

22. Young, supra note 18, at 250.

23. Keohane, supra note 12 , at 52.

24. Id.

25. Stephan Krasner, Regimes \& The Limits of Realism: Regimes as Autonomous Variables, 36 INT'L ORG. 497, 498 (1982). Joseph Grieco, Anarchy \& The Limits of Cooperation: A Realist Critique of the Newest Liberal Internationalism, 42 INT'L ORG. 485 (1988).

26. Keohane, supra note 5 , at 529.

27. Robert KeOHANe, international institutions \& State Power: Lessons in INTERNATIONAL RELATIONS THEORY vii (1989).

28. Id. at 8 . 
because they provide structure in the international system, disseminate information, establish norms of behavior, and incentivize repeated interstate interaction and collaboration which reduce the effects of, but do not eliminate, the anarchic security dilemma..$^{30}$

Liberalism offers a unique alternative to realism and institutionalism in modern international relations theory. Whereas realists and institutionalists view states as "billiard balls" 31 or "opaque single units," 32 liberalists regard states' behaviors as functions of the configuration and intensity of domestic interests within their internal structures. ${ }^{33}$ Liberalists argue that "[s]tate behavior is ... determined not by the international balance of power, whether or not mediated by institutions, but by the relationship between [individuals and groups operating in both domestic and transnational civil society] and the governments representing their interests, in varying degrees of completeness." 34

\section{B. The Relationship Between International Relations Theory \& International Law}

The primary schools of international relations theory have much in common with principles underlying international law, despite the traditional separation of the disciplines. Both realist theory and traditional international law place states at the center of the international system and pay little attention to idiosyncratic characteristics internal to states. ${ }^{35}$ States serve as the foundational unit for realist explanations of the international system and for traditional rules of international law. Moreover, both institutionalists and international lawyers agree that "rules, norms, principles, and decision-making procedures can mitigate the effects of anarchy and allow states to cooperate in the pursuit of common ends." 36 Liberalism shares international law's assumption that states pursue interests rather than power, that rules of deference are likely appropriate when one state's interests exceed another state's interests, and that transnational legal norms are possible when states' interests are aligned. ${ }^{37}$

Given these commonalities, international relations theory may be used to place international law in a broader context and supplement the study of international law by permitting inquiry beyond technical and formalistic

29. See e.g., John Ruggie, Multilateralism: The Anatomy of an Institution, 46 INT’L ORG. 561 (1992).

30. Slaughter, supra note 10, at 726. KEOHANE, supra note 12 , at 245 .

31. Waltz, supra note 9.

32. Anne-Marie Burley, International Law \& International Relations Theory: A Dual Agenda, 87 AM. J. INT'L L. 205, 227-228 (1993).

33. Andrew Moravcsik, Liberalism \& International Relations Theory, Center for International Affairs Working Paper (Harvard, 1992).

34. Slaughter, supra note 10 , at 728. Id. at 6.

35. Slaughter, supra note 10, at 722. See generally Bardo Fassbender, International Law \& International Relations Theory: Building Bridges, 86 AM. SOC’Y INT’L L. PROC. 167 (1992).

36. Slaughter, supra note 10, at 724-25.

37. Larry Kramer, Vestiges of Beale: Extraterritorial Application of American Law, 1991 SuP. CT. REV. 179, 213-221 (1991). 
positivist approaches to law. International relations theory "illuminate[s] and challenge[s] the assumptions about the international system that international lawyers consciously or unconsciously rely on to shape their mental map of the international system" 38 and equips international lawyers "with powerful theoretical and rhetorical tools to specify the nature and causes of substantive problems and the types of regulatory regimes appropriate to deal with them." 39 International relations theory therefore permits lawyers to analyze the efficacy of specific international laws, ${ }^{40}$ "to diagnose international policy problems and to formulate solutions to them," and "to examine and reconceptualize particular institutions." 41 International relations theory may also be used to assist legal scholars understand the development of international law in terms of forces internal to a sovereign state. 42 In short, international relations theory permits more expansive inquiry into the merits and coherence of international legal rules. ${ }^{43}$

Liberalism, consistent with its focus on the impact of domestic influences upon states' international behavior, asserts that transnational law is a subset of international law. 44 Initially conceived by Phillip Jessup, ${ }^{45}$ transnational law refers to "all domestic law bearing on international relations and law regulating relations between governments and foreign nationals." 46 According to liberalism, then, domestic laws with extraterritorial effects and legal doctrines with foreign affairs implications are properly classified within the corpus of international law. Thus, as holds for international relations theory and traditional international law, liberal international relations theory may also enhance inquiry into the efficacy of domestic legal doctrines with international effects. After a brief overview of the role of United States courts in foreign affairs, the remaining sections draw upon a particular subset of liberal international relations theory, liberal internationalism, to consider the merits and coherence of the act of state doctrine in United States courts. Consistent with liberal internationalist theory, United States courts manipulate situs to suit their desired application of the act of state doctrine based upon certain extrajudicial factors.

\section{The Role of United States Courts in Foreign AfFairs}

The United States Constitution primarily vests foreign affairs power in Congress and the Executive. As enumerated in the Constitution, Congress

\footnotetext{
38. Slaughter, supra note 10, at 724-25.

39. Slaughter, Tulumello \& Wood, supra note 8 , at 375.

40. Id. at 378 .

41. Id. at 373 .

42. Id. at 378

43. Abbott, supra note 3 , at 336, 340 .

44. Slaughter, Tulumello \& Wood, supra note 8, at 382.

45. See generally PHILLIP JESSUP, TRANSNATIONAL LAW (1956).

46. Slaughter, Tulumello \& Wood, supra note 8 , at 382 .
} 
may regulate foreign commerce, raise armies and navies and make rules for their regulation, declare war, define and punish the laws of nations, grant letters of marquee and reprisal, and appropriate funds. ${ }^{47}$ The enumerated powers of the Executive include the power to appoint ambassadors, to receive ambassadors, to enter into treaties with consent of the Senate, to serve as commander-in-chief of the armed forces, and to ensure that the laws of the United States are faithfully executed. ${ }^{48}$ The foreign affairs powers of the Judiciary, in comparison, are rather circumscribed. The Constitution permits the Judiciary to hear cases arising out of treaties, to hear cases affecting ambassadors, and to hear cases involving foreign nations and citizens. ${ }^{49}$

Formally, then, courts in the United States serve a limited function in foreign affairs by design. Courts lack the institutional capacity to adequately handle sensitive international relations issues. They do not have the "necessary informational resources, the ability to adjust to diplomatic nuance and timing, and the appropriate remedial resources to respond to the international political dynamic." 50 Moreover, the public nature of the courts "inherently conflicts with the requirements of international political dispute resolution," and "[t]heir process, the methodology of the common law, is fundamentally at odds with the dynamic process of power adjustment that is the stuff of international diplomacy." 51 There is indeed an entire "body of case law and statutory authority that purports to keep the courts out of foreign policy." 52

Yet, in practice, it is unclear which cases so directly implicate foreign affairs considerations that judicial involvement becomes unconstitutional or otherwise inappropriate. International economic, social, cultural, and political connectivity increased rapidly in the latter half of the $20^{\text {th }}$ and early $21^{\text {st }}$ century. This rise in cross-border interactions, known commonly as globalization, implies a tightly correlated increase in the number of interstate legal relationships and disputes. Despite their institutional weaknesses, United States courts may be well suited to adjudicate many of these disputes. As Justice Brennan stated succinctly in Baker v. Carr, "it is error to suppose that every case or controversy which touches foreign relations lies beyond judicial cognizance." 53 Consistent with this view, judges have developed an array of doctrines, principles, rules of deference, balancing tests, and other mechanisms of judicial restraint to guide judicial determinations of their competence to hear cases involving foreign affairs. These mechanisms include, predominately, foreign sovereign immunity, the political question doctrine, extraterritoriality, interest balancing, and the

47. U.S. CONST. art. $1, \int 8$.

48. U.S. CONST. art. 2, \$\$ 2-3.

49. U.S. CONST. art. $3, \$ 2$.

50. Jack Garvey, Judicial Foreign Policy-Making in International Civil Litigation: Ending the Charade of Separation of Powers, 24 LAW \& POL'Y INT'L BUS. 461, 462 (1992).

51. Id.

52. Id. at 461.

53. Baker v. Carr, 369 U.S. 186, 211 (1962). 
act of state doctrine. ${ }^{54}$ At their discretion, courts may also defer to Executive interpretations of treaties and statutes that implicate foreign affairs considerations. ${ }^{55}$

Arguably, however, courts' delineation of these mechanisms is itself an exercise of authority beyond their constitutional purview. Some scholars assert that judges must only evaluate the facts and interpret the law of a particular case and should not attempt to analyze its international political implications. ${ }^{56}$ They contend that any judicial determination that a case does or does not implicate foreign affairs is itself an improper exercise of judicial authority, and that judges should instead decide to hear or dismiss such cases on the basis of non-political judicial tools, such as conflicts of laws analysis and forum non-conveniens. ${ }^{57}$ Others scholars argue that the mechanisms may be erroneously applied and serve as tools for the courts to impermissibly expand their foreign affairs authority "through a refined set of intellectual manipulations." 58

\section{The ACt of State Doctrine in United States Courts \& Flaws IN ITS TRADITIONAL \& REVISIONIST INTERPRETATIONS}

The act of state doctrine bars courts from reviewing the validity of acts taken by a foreign government within that government's own territory and is perhaps the most controversial mechanism courts employ to determine the justicability of cases involving foreign affairs. The doctrine has been critiqued as overly malleable and for producing inconsistent results. ${ }^{59}$ Indeed, "even though the doctrine has spawned a wealth of cases and scholarly writings, there has been little agreement on the exact scope of the doctrine or the policies underlying its application." 60

Despite the confusion, traditional interpretations of judicial application of the act of state doctrine may generally be divided into two categories. The first category classifies the act of state doctrine as a rule of external deference to foreign sovereigns. From this perspective, the act of state doctrine directs courts to consider foreign states' acts as binding law absent well-recognized exceptions of public policy and international law. ${ }^{61}$ The second category classifies the act of state doctrine as a rule of internal deference to the Executive. Proponents of this view assert that the act of state doctrine delimits judicial competence to adjudicate politically

\footnotetext{
54. Garvey, supra note 50, at 462.

55. See e.g., Mingtai Fire \& Marine Ins. v. United Parcel Service, 177 F.3d 1142 (1999). Gonzalez. v. Reno, 215 F.3d 1243 (2000). De Los Santos Mora v. New York, 129 S.Ct. 397 (2008). Goldwater v. Carter, 444 U.S. 996 (1979). Williams v. Suffolk. Ins. Co., 38 U.S. 415 (1839).

56. Garvey, supra note 50, at 498.

57. Id.

58. Id. at 461.

59. See generally Michael Bazyler, Abolishing the Act of State Doctrine, 134 PENN L. REV. 325 (1986).

60. Matthew Alderton, The Act of State Doctrine: Questions of Validity \& Abstention from Underbill to Habib, 12 MEL. J. INT'L L. 1, 2 (2011). Id. at 327.

61. Anne-Marie Burley, Law Among Liberal States: Liberal Internationalism \& the Act of State Doctrine, 92 COLuM. L. REV. 1907, 1928 (1992).
} 
sensitive disputes and requires courts to defer to Executive guidance on how best to proceed. ${ }^{62} \mathrm{~A}$ brief history of the act of state doctrine will illustrate the shortcomings of these interpretations.

\section{A. Origins \& Traditional Interpretations of the Act of State Doctrine}

The act of state doctrine developed as a common law rule in $17^{\text {th }}$ century England derived from principles of comity, sovereign immunity, and non-intervention into states' domestic affairs. ${ }^{63}$ The English courts felt that "it remained the province of the executive to conduct a state's foreign affairs and that the judiciary should not involve itself (or bring into jeopardy) the conduct of such affairs." 64 The doctrine entered the American legal tradition in Underbill v. Hernandez, an 1867 Supreme Court case. ${ }^{65}$ In Underbill, the Court expressed the doctrine's classic formulation: "every sovereign state is bound to respect the independence of every other sovereign state, and the courts of one country will not sit in judgment of another, done within its own territory. Redress of grievances by reason of such acts must be obtained through the means open to be availed of by sovereign powers as between themselves." 66 The Court in Underbill applied the act of state doctrine to bar review of the Venezuelan military's detention of an American citizen and confiscation of the citizen's property. ${ }^{67}$

Consistent with the doctrine's formulation in Underbill, courts in subsequent cases tended to rely upon comity and avoidance of international conflict as the bases for invoking the doctrine.68 For example, in Oetjen v. Central Leather Co., a 1918 Supreme Court case, the Court applied the act of state doctrine to the Mexican government's expropriation of goods, refusing to adjudicate the dispute. ${ }^{69}$ The Court stated that "the highest considerations of international comity and expedience demand ... [that] the conduct of one independent government cannot be successfully questioned in the courts of another."70 Moreover, according to the Court, to "permit the validity of the acts of one sovereign state to be reexamined and perhaps condemned by the courts of another would very certainly imperil the amicable relations between governments and vex the peace of nations." 71 In sum, early judicial applications of the act of state doctrine adhered to the notion that " $[t]$ he very meaning of sovereignty is that the decree of the sovereign makes law." 72

\footnotetext{
62. Id.

63. Blad v. Bamfield, 3 Swans 604 (1674). Alderton, supra note 60, at 3.

64. Alderton, supra note 60 , at 3.

65. Underbill v. Hernander, 168 U.S. 250 (1867).

66. Id. at 252 .

67. Id. at 254.

68. Alderton, supra note 60 , at 4.

69. Oetjen v. Central Leather Co., 246 U.S. 297, 304 (1918).

70. Id. at 303-04.

71. Id. at 304. Alderton, supra note 60, at 4-5.

72. American Banana Co. v. United Fruit Co., 213 U.S. 347, 349 (1909).
} 
Beginning in the middle of the $20^{\text {th }}$ century, however, courts began to cite separation of powers principles as the basis for invoking the doctrine. Rather than relying exclusively upon notions of comity, the Supreme Court emphasized that "it remained the duty and province of the executive arm of government to conduct foreign affairs, and that the judiciary should refrain wherever possible from interfering with this prerogative." 73 The court thus recognized that principles apart from comity may guide application of the act of state doctrine. In United States v. Pink, the Supreme Court applied the act of state doctrine on the basis of the Executive's foreign affairs authority, comity, and territorial sovereignty. ${ }^{74}$ In Bernstein v. Van Heyghen Freres, S.A., a 1947 Supreme Court case involving Nazi expropriation, Justice Hand inquired "whether, since the cessation of hostilities with Germany, the Executive, which is the authority to which we must look for the final word in such matters, has declared that the [act of state doctrine] does not apply." 75

The Supreme Court's 1964 decision in Banco Nacional de Cuba v. Sabbatino confirmed the importance of separation of powers principles to judicial application of the act of state doctrine. ${ }^{76}$ Sabbatino involved a Cuban government decree nationalizing American-owned sugar companies. ${ }^{77}$ The Court applied the act of state doctrine to the nationalization, emphasizing the "constitutional underpinnings" of the doctrine. ${ }^{78}$ The Court observed that although the "historic notions of sovereign authority do bear upon the wisdom of employing the act of state doctrine, they do not dictate its existence." 79 Rather, the act of state doctrine "arises out of the basic relationships between branches of government in a system of separation of powers... [it] concerns the competency of dissimilar institutions to make and implement particular kinds of decisions in the area of international relations." 80 For the Court, the "continuing vitality [of the doctrine] depend[ed] on its capacity to reflect the proper distribution of functions between the judicial and political branches of the Government on matters bearing upon foreign affairs." 81

If the Court intended Sabbatino to mark the abandonment of the act of state doctrine as a rule of external deference and recast it as a rule of internal deference, the effort largely failed. Indeed, the Court's act of state jurisprudence since Sabbatino has been muddled. In First National City Bank v. Banco National de Cuba ${ }^{82}$ and Alfred Dunbill of London v. Republic of Cuba, ${ }^{83}$

\footnotetext{
73. Alderton, supra note 60 , at 5 .

74. United States v. Pink, 315 U.S. 203, 233 (1942).

75. Bernstein v. Van Heyghen Feres, 163 F.2d 246, 249-50 (1942). Burley, supra note 61, at 1931

76. Banco Nacional de Cuba v. Sabbatino, 376 U.S. 398, 423 (1964).

77. Id.

78. Id. at $400-06$.

79. Id. at 421. Alderton, supra note 60, at 5-6.

80. Sabbatino, 376 U.S. at 423

81. Id. at 427-28.

82. First National City Bank v. Banco National de Cuba, 406 U.S. 759 (1972).

83. Alfred Dunbill of London v. Republic of Cuba, 425 U.S. 682 (1976).
} 
the Court splintered badly, drafting only plurality opinions. The presiding justices held vastly disparate conceptions of the doctrine, disagreeing on fundamental issues such as the role of interest balancing, ${ }^{84}$ whether the doctrine is a foreign affairs political question doctrine, ${ }^{85}$ and the existence of a commercial activities exception. 86

Fundamental disagreement regarding the role of the act of state doctrine persists in lower court opinions and legal scholarship. ${ }^{87}$ Some lower courts consider both comity and separation of powers principles in applying the doctrine. Other courts assert that "the doctrine is neither compelled by the Constitution nor dictated by respect for sovereign authority." 88 Legal scholars critique these approaches, pointing out that "[w] hether to apply foreign law based on notions of territorial sovereignty, power, or choice of law factors may have nothing to do with whether judicial action will conflict with particular goals of foreign policy that the executive may wish to advance for political ends." 89 As this brief history demonstrates, classifying the act of state doctrine as either a rule of external deference or a rule of internal deference fails to properly synthesize and explain the doctrine as a coherent whole.

So classifying the act of state doctrine also raises several constitutional concerns. For example, the conception of the act of state doctrine as a rule of external deference governed by choice of law analysis concedes the certainty of disparate outcomes in similar cases based solely upon the content of state choice of law rules. Because "[i] $t$ is fundamental to our constitutional scheme that in dealing with other nations the country must speak with a united voice... it would be baffling if a foreign act of state... were ignored on one side of the Hudson but respected on the other; any such diversity between states would needlessly complicate the handling of the foreign relations of the United States." 90 Moreover, adherence to the conception of the act of state doctrine as a rule of internal deference risks improper Executive influence on the courts. ${ }^{91}$ In other words, "[i]f courts obediently followed executive positions on whether judicial power should be exercised in act of state cases, then the executive becomes the decision-maker and, in effect, usurps the judicial power from the courts ... reduc[ing] [the judiciary] to a mere errand boy for the Executive Branch ... tarnish[ing] the image of the judiciary as an independent branch of government." 92

\footnotetext{
84. Id. at 729-30. Banco National de Cuba, 406 U.S. at 774-776.

85. Banco National de Cuba, 406 U.S. at 764-770.

86. Alfred Dunbill, 425 U.S. at 695-706, 715, 724-30.

87. See, e.g., Allied Bank Int'l v. Banco Credito Agricola de Cartago, 757 F.2d 516, 521 (1985). Callejo v. Bancomer, S.A., 764 F.2d 1101, 1113 (1985).

88. Margaret Tahyar, The Act of State Doctrine: Resolving the Debt Situs Confusion, 86 COLUM. L. REV. 594, 607-08 (1986).

89. Daniel Chow, Retbinking the Act of State Doctrine: An Analysis in Terms of Jurisdiction to Prescribe, 62 WASH. L. REV. 397, 446 (1987).

90. Republic of Iraq v. First Nat'l City Bank, 353 F.2d 47, 50-51 (1965).

91. Chow, supra note 89, at 436.

92. Id. Banco National de Cuba, 406 U.S. at 773.
} 


\section{B. Revisionist Interpretations of the Act of State Doctrine}

Recognizing the shortcomings of the traditional interpretations of the act of state doctrine, revisionist legal scholars have rejected the characterization of the doctrine as a rule of external deference or a rule of internal deference and have attempted to synthesize the doctrine's jurisprudence via other approaches, hoping to salvage the doctrine as a meaningful judicial tool. Other scholars argue that the act of state doctrine is an improper judicial tool and simply advocate for its abolition. Both groups of scholars ignore methods necessary to properly understand the act of state doctrine, and consequentially, their assertions are unconvincing.

One revisionist scholar argues that the conception of the act of state doctrine as a rule of internal deference encompasses external deference. ${ }^{93}$ That is, the "Sabbatino court was concerned about internal separation of powers issues, but not out of rigid formality ... the reason for concern in Sabbatino was that an internal violation of powers could cause problems for American foreign policy and anger other nations needlessly." 94 From this perspective, the Sabbatino decision expanded the scope of the act of state doctrine but did not represent a major doctrinal shift from the Court's articulation in Underbill. Whereas "Underbill applied the Act of State Doctrine as an inflexible rule... Sabbatino changed act of state jurisprudence by imposing a discretionary test applied on a case-by-case basis." 95

Another revisionist scholar asserts that the act of state doctrine is best understood in the context of the jurisdiction to prescribe. ${ }^{96}$ In other words, judicial application of the act of state doctrine rests upon whether the act was a proper exercise of the sovereign's jurisdiction to prescribe. Jurisdiction to prescribe refers to "the appropriate authority of a state to make its law applicable to the activities, relations, or status of persons, or the interests of persons in things." 97 Modern conceptions of the jurisdiction to prescribe recognize that "[n]ational laws are now not only effective within the territory of the prescribing sovereign, but, under certain circumstances, are now generally recognized as effective within the territory of a foreign sovereign ... [and that] [t] he proper scope and limits of sovereign lawmaking authority no longer are based on concepts of power and territoriality alone, but on a careful evaluation of interests, contacts, traditions, and expectations that together determine the reasonableness required by international law." 98 From this perspective,

93. See generally Andrew Patterson, The Act of State Doctrine is Alive and Well: Why Critics of the Doctrine Are Wrong, 15 CAL. L. REV. 111 (2009).

94. Id. at 118 .

95. Id.

96. See generally Chow, supra note 89.

97. Id. at 400 .

98. Id. at 448-49. See e.g., RESTATEMENT (THIRD) OF FOREIGN RELATIONS LAW OF THE UNITED STATES \402 (1988) ("a state has jurisdiction to prescribe law with respect to ... the 
sovereign acts must be recognized as valid as long as the sovereign acted properly within its lawmaking authority. ${ }^{99}$

These revisionist efforts to synthesize the act of state doctrine are unhelpful. The argument that the act of state doctrine is simultaneously a rule of external deference and a rule of internal deference, as the latter subsumes the former, merely restates the traditional conceptions of the doctrine in a manner that is more difficult to apply. Furthermore, analysis of act of state jurisprudence in terms of jurisdiction to prescribe is also complex and, in any event, reduces to a rule of external deference, thereby adding little to the act of state doctrine's traditional interpretations. The question of whether a state acted reasonably within its jurisdiction to prescribe is a question of law to be determined by reference to several factors. 100 Yet, "[w]hen more than one state has a reasonable basis to exercise jurisdiction to prescribe over persons or conduct, each state should evaluate its own interests as well as those of the other state in exercising such jurisdiction... [e]ach state should make this evaluation in light of all the relevant factors... and should defer to the other state if that state's interest is clearly greater."'101

Given the shortcomings of revisionist interpretations of the doctrine, other scholars have abandoned efforts to synthesize act of state jurisprudence into a coherent whole. These scholars describe the doctrine as a "tangled web"102 and advocate for its abolition.103 One scholar laments that "neither courts nor commentators have been able to agree on the exact scope of the doctrine or the policies underlying its application."104 This scholar argues that because "the doctrine is applied inconsistently, and parties structuring an international transaction often cannot predict whether the doctrine will prevent adjudication of claims arising from the transaction, ... the act of state doctrine ... should be abandoned."105 Through perhaps an extreme proposition, advocates for the doctrine's abolition underscore mounting frustration surrounding judicial application of the doctrine.

activities, interests, status or relations of its nationals outside as well as within its territory"). See also United States v. Yunis, 924 F.2d 1086, 1091 (1991) (interpreting the statute at issue to authorize the prosecution of foreign nationals for their activities abroad).

99. Id.

100. Restatement (Third) OF Foreign Relations LAW of the United States $\$$ 403(1)(2) (1988).

101. Chow, supra note 89 at 453-54.

102. Gregoy Fox, Reexamining the Act of State Doctrine: An Integrated Conflicts Analysis, 33 HARV. INT'L L. J. 521, 568 (1992).

103. Bazyler, supra note 59.

104. Id. at 327.

105. Id. at 398 . 


\section{INTERPRETING THE ACT OF STATE DOCTRINE Via LibERAL INTERNATIONAL RELATIONS THEORY}

Judges, lawyers, and legal scholars concede that the act of state doctrine has rested upon varied bases since its first introduction into the American legal tradition. Despite exhaustive attempts to synthesize these bases into a holistic account of judicial application of the doctrine, the doctrine remains little understood. Examined entirely from a legal perspective, the doctrine appears incoherent. Yet, as a legal doctrine with foreign affairs implications, international relations theory can provide the necessary framework for understanding the act of state doctrine. As a domestic legal doctrine, liberal international relations theory is particularly useful in examining its efficacy.

\section{A. Liberal Internationalism \& The Model of Transnational Legal Relations}

A subset of liberalism, liberal internationalist theory explains differences in liberal and illiberal states' behavior in the international system as a function of domestic political institutions. ${ }^{106}$ The liberal internationalist model of transnational legal relations posits that legal relations between states are highly dependent upon the composition of the dyad in question. ${ }^{107}$ Legal relations between two liberal states are likely to be markedly different from legal relations between a liberal state and an illiberal state or between two illiberal states. 108

Transnational legal relations between liberal-liberal and liberal-illiberal dyads differ because liberal states operate pursuant to entirely different ordering principles than do illiberal states. ${ }^{109}$ The distinction between states as either liberal or illiberal depends upon several factors including the extent to which the state exhibits a representative constitutional government, separation of powers, free market economics, protection of private property rights, and respect for human rights. ${ }^{110}$ Liberal states "operate in a 'zone of law' in which domestic courts regulate transnational relations under domestic law[,] [and] ... [c]ourts within this zone evaluate and apply the domestic law of foreign states in accordance with general pluralist principles of mutual respect and interest-balancing."111 Illiberal states, in contrast, "operate in a 'zone of politics,' in which domestic courts either play no role in the resolution of transnational disputes or allow themselves to be guided by the political branches."112

When two liberal states engage in transnational legal relations, the states recognize the potential for "legitimate difference." 113 The shared common

106. Burley, supra note 61, at 1917.

107. Id.

108. Id.

109. Id. at $1920-21$

110. $I d$.

111. Id. at 1910.

112. $I d$.

113. Id. at 1919. 
values between these states, especially a commitment to the rule of law and principled decision-making, ensure that liberal "states can disagree with the specific policy choices embedded in each other's national laws but nevertheless respect those laws as legitimate means to the same ultimate ends." 114 Moreover, when laws within a particular liberal state clearly offend values common to other liberal states, the courts of other liberal states are free to reject these laws upon reasoned deliberation, engaging in a form of dialogue with the courts of the offending state. ${ }^{115}$

According to the liberal internationalist model, transnational legal relations between liberal and illiberal states are less predictable. Judges in illiberal states are less likely to engage in principled decision-making consistent with the rule of law. ${ }^{116}$ Even if principled decision-making occurs, the lack of shared political, economic, and social values decreases the likelihood of recognizing legitimate difference. ${ }^{117}$ Moreover, liberal judges are likely to fear escalation of tensions or war between the two states, rendering them less willing to denounce illiberal states' laws or decisions. Thus, in contrast to the interaction between courts in liberalliberal dyads, courts in liberal states are less likely to engage in reciprocal dialogue with courts in illiberal states. 118 Indeed, "[t]he combination of fundamental ideological conflict, the shadow of actual military conflict, and the difficulty of judicial dialogue might reasonably push the courts of liberal states toward the conclusion that cases involving the laws of illiberal states are literally beyond law ... [and that] [s]uch cases should instead be referred to the political branches for resolution." 119

\section{B. The Liberal Internationalist Model's Explanation of the Act of State Doctrine}

Liberal international relations theory and the liberal internationalist model provide the framework necessary for a holistic and coherent interpretation of the act of state doctrine. The act of state doctrine may not be properly understood though an indiscriminate examination of its application to all states. Rather, it is necessary to bifurcate United States act of state jurisprudence into cases involving liberal states and cases involving illiberal states. The political structure of states within a transnational legal dyad drives judicial application of the doctrine. Of course, as with many theories, liberal internationalism's zone of law and zone of politics distinction may not precisely describe judicial decision-making in every case between liberal-liberal and liberal-illiberal dyads. However, the

114. Id.

115. Id. at 1919-20. See e.g., Soering v. United Kingdom, 161 Eur. Ct. H.R. (ser. A) (1989) (holding that extradition to the United States to face capital charges violated basic human rights principles enshrined in provisions of the European Convention on Human Rights).

116. Burley, supra note 61, at 1921.

117. Id.

118. Id.

119. Id. 
distinction is useful as the starting point from which to begin examination of more specific factors influencing courts within particular dyads.

Judicial application of the act of state doctrine to acts of liberal states is consistent with its conception as a rule of external deference. ${ }^{120}$ Courts in liberal-liberal dyads examining the acts of a foreign state are free to judge the validity of the act within the bounds of shared liberal values, balance each state's interests in the preservation of the act's validity, and, recognizing the scope of legitimate difference, adjudicate the dispute.121 Judicial application of the doctrine to acts of illiberal states is consistent with its conception as a rule of internal deference. ${ }^{122}$ Courts in liberalilliberal dyads examining the acts of a foreign state are likely to yield to one of two disparate impulses. ${ }^{123}$ First, "the underlying determination that the dispute in question is meet for political rather than legal resolution could... lead to increased receptivity to direction from the political branches."124 Second, "the rule-of-law values said to animate liberal courts might lead such courts to resist direction from the political branches regarding the legal resolution of the case before them" and refuse to adjudicate the dispute citing separation of powers principles. ${ }^{125}$ In this way, liberal international relations theory and the liberal internationalist model of transnational legal relations unify otherwise disparate legal interpretations of the act of state doctrine. ${ }^{126}$

The liberal internationalist model is more than simply a paradigm for interpreting judicial application of the act of state doctrine at a high level of abstraction. The liberal internationalist model may also be used to predict the outcome of particular cases ex ante or explain their outcome as a function of specific factors. The utility of the liberal internationalist model as a predictive or explanatory tool requires a recognition that judges do not apply the doctrine simply as a rule of external deference or a rule of internal deference on the basis of a classification of foreign states as either liberal or illiberal. ${ }^{127}$ Rather, the liberal internationalist model explains that judges apply the act of state doctrine on the basis of particular factors relevant to transnational legal relations between states. ${ }^{128}$ Judges analyze these factors in each case to reach a decision regarding the proper application of the act of state doctrine. ${ }^{129}$

Factors influencing decision-making in cases involving illiberal states include: (1) the awareness of the limitations of judicial competence, (2) the existence of a diplomatic dispute resolution initiative, (3) the position of

120. Id. at 1942 .

121. Id. at 1912.

122. Id. at 1942.

123. Id. at $1911-12$

124. $I d$.

125. Id.

126. Id. at 1910.

127. Id. at 1963.

128. $I d$.

129. Id. 
the Executive, and (4) the judicial belief as to the relative role of the political branches in foreign affairs. ${ }^{130}$ Factors influencing decisionmaking in cases involving liberal states include: (1) the validity of the act under United States or foreign law, (2) the position of the foreign government, (3) the balance of interests between the United States and the foreign state, (4) the likelihood of reciprocity, and (5) the relative insensitivity to political dimensions of the dispute. According to the liberal internationalist model, judicial application of the act of state doctrine can be explained by examining these factors in the context of particular cases. ${ }^{131}$

\section{Usefulness of Situs to Test the Liberal Internationalist Interpretation of the Act of State Doctrine}

The territorial requirement of the act of state doctrine in intangible property cases offers a unique opportunity to examine the efficacy of the liberal internationalist model's explanation of the doctrine. According to the model, judges deciding cases implicating the act of state doctrine and involving illiberal states are likely to be more receptive to certain extrajudicial factors regarding whether the doctrine should apply. Yet, the act of state doctrine has elements that, when satisfied, compel its application. United States courts must apply the act of state doctrine to official acts of a foreign sovereign occurring exclusively within the sovereign's territory, and courts must justify application or non-application of the doctrine on the basis of these elements. Because the territorial inquiry of the act of state doctrine in intangible property cases is highly malleable, courts can manipulate the inquiry to find the territorial requirement of the act of state doctrine either fulfilled or unfulfilled at will.

A situs determination is at the heart of this territorial inquiry. Situs refers to an item's "location or position ... for legal purposes." 132 Several rules for determining situs in intangible property cases have emerged. These rules include the "jurisdiction over the debtor" rule, the "complete fruition" rule, and the "incidents of debt" rule. 133 Very little consensus exists regarding which rule is most appropriate. Based upon the particular rule applied, situs may be located either within the territory of the foreign sovereign or elsewhere. From the perspective of the liberal internationalist model, a court's situs determination in intangible property cases serves as a proxy for the court's more general desire to apply or withhold application of the act of state doctrine on the basis of extrajudicial factors. ${ }^{134}$ That is, because situs is so malleable, courts can locate situs in whichever location, either inside or outside the foreign state, suits their desired application of the act of state doctrine.

130. Id. at 1964.

131. Id.

132. BLACK'S LAW DiCTiONARY (9th ed. 2009).

133. See generally Tahyar, supra note 88 , at 596-604.

134. Burley, supra note 61, at 1973. 
The remainder of this paper examines a small subset of cases as a first step towards establishing the efficacy of the liberal internationalist model's explanation of the act of state doctrine. Comparisons of courts' situs determinations in intangible property cases will illuminate the validity of the liberal internationalist model's characterization of the act of state doctrine. The following section examines United States judicial opinions involving acts of the Russian state nationalizing property and confiscating debt following the Russian Revolution. Because each of the cases arises from similar events, they provide a good baseline for initial analysis.

\section{THE EFFICACY OF THE LIBERAL INTERNATIONALIST INTERPRETATION OF THE ACT OF STATE DOCTRINE IN RUSSIAN CASES}

In 1917, Russia experienced a series of political upheavals that ultimately led to the overthrow of the Tsarist aristocracy and the establishment of the Soviet Union. ${ }^{135}$ The revolution began in March of 1917 when the Emperor, Nicholas II, abdicated and was replaced by the Russian Provisional Government, comprised of former members of the Duma. The Provisional Government temporarily exercised authority alongside radical socialist factions. However, when the Provisional Government persisted in fighting Germany in World War I, the Bolsheviks resisted. The Bolsheviks, led by Vladimir Lenin, overthrew the Provisional Government and ultimately signed the Treaty of Brest-Litovsk, ending the war with Germany in March of 1918. Consolidating their power and fulfilling their socialist agenda, the newly installed Soviet government engaged in widespread nationalization and confiscation of private property. The following cases arise from these events.

\section{A. Sokoloff}

In Sokoloff v. National City Bank of New York, Boris Sokoloff paid \$30,000 to the National City Bank of New York in 1917 to open an account in the bank's Petrograd branch, the funds payable upon demand in rubles. ${ }^{136}$ Later that year, in November 1917, the Soviet government, by decree, nationalized all private joint stock banks organized under Russian law or operating within Russia, merging them with the Russian State Bank, and confiscated all deposit accounts via a revolutionary tax.137 After the decrees, Sokoloff attempted to withdraw funds from the Petrograd branch of National City Bank, but his demands were refused.138 Sokoloff then filed suit against the bank in New York to recover his lost assets. 139

135. See generally LeON TrotSky, History of THE Russian REVOlution (1980).

136. Sokoloff v. National City Bank of New York, 239 N.Y. 158, 162 (1924).

137. Id. at 163 .

138. Id. at 162 .

139. Id. 
National City Bank argued that the decrees transferred all of the branch bank's assets and liabilities to the Russian State Bank and that, as Russian acts of state, these decrees could not be invalidated in New York courts. ${ }^{140}$ Consequentially, National City Bank argued that the decree absolved them of any liabilities toward Sokoloff. ${ }^{141}$ Sokoloff argued in response that because the United States did not recognize the Soviet government, the decrees could not be regarded as valid acts of state. ${ }^{142}$ Moreover, Sokoloff argued that even if the Soviet government was deemed the de facto government of the Russian state, the act of state doctrine was inapplicable because the situs of the debt at issue was the United States. ${ }^{143}$ Sokoloff based this assertion on the fact that National City Bank was headquartered in the United States, the initial deposit was made in the United States, and the depository contract was formed in the United States.

The court dispensed with Sokoloff's first contention, determining to regard the Soviet government as the de facto government of the Russian state for the purposes of the act of state doctrine. ${ }^{144}$ In its discussion of situs, the court acknowledged the intangible nature of the property in question. The court stated that " $[\mathrm{t}]$ he res belonging to the plaintiff was not a physical object committed to the defendant's keeping, but an intangible right, a chose in action, the right to receive rubles in the future under an executory contract." 145 The court then disagreed with Sokoloff's contention that the United States was the situs of the debt. Instead, the court located situs in Russia, relying upon the location of National City Bank's branch in Petrograd. ${ }^{146}$ According to the court, "[t]he intangible chose in action, at least when it is the result of a deposit in a bank, has for some purposes a situs at the residence or place of business of the debtor, though the creditor be far away... [t] he debtor in this instance, though domiciled in the United States ... had what was equivalent to a residence in Russia while it was doing business at its Russian branch."147 As a result, the court applied the act of state doctrine and refused to invalidate the Russian decrees.

The court in Sokoloff, however, avoided the most logical implication of a straightforward application of the act of state doctrine. While a straightforward application of the doctrine would confirm the validity of the Soviet decrees transferring the assets and liabilities of National City Bank's Petrograd branch to the Russian State Bank, the court interpreted the timing of the decrees to maintain the transfer of the branch bank's assets but not the transfer of its liabilities. ${ }^{148}$ The court separated the

140. Id. at 163 .

141. Id.

142. Id. at 161.

143. Id. at 161-62.

144. Id. at 161

145. Id. at 166 .

146. Id. at 169 .

147. Id.

148. Id. at 167. 
nationalization decree and the confiscation decree into two distinct stages. Regarding the first stage, the nationalization decree, the court stated that "[t]he defendant's liability was unaffected by [this] attempt to terminate its existence."149 Because the nationalization decree was directed at the bank, not the depositors, and because the bank was a corporation with continued existence outside Russia, the obligation to pay Sokoloff under the depository contract remained with National City Bank as a single corporate entity. ${ }^{150}$ The court then expressed that although the second stage, the revolutionary tax levied upon depositors, may have absolved National City Bank of its liability if issued in isolation, it did not do so when issued after the nationalization decree. According to the court, because "[a]t the time of [the second decree], the Russian assets were already lost... [t] he defendant did not surrender them or any part of them for the purpose of discharging a tax or other liability imposed on its depositors."151 That is, the "decree of confiscation directed against depositors [did] not reduce the liabilities of [National City Bank because it had] already yielded up its assets in virtue of a decree of confiscation directed against itself."'152

\section{B. Day-Gormley}

In Day-Gormley Leather Co. v. National City Bank of New York, a case arising ten years after Sokoloff but from similar facts, the court engaged in a markedly different analysis. ${ }^{153}$ In that case, the Day-Gormley Leather Company deposited funds directly at National City Bank's Petrograd branch prior to the Soviet government's nationalization and confiscation decrees. ${ }^{154}$ After the decrees, Day-Gormley demanded its deposits from the Petrograd branch but was denied payment. ${ }^{155}$ Then, because the deposit contract between Day-Gormley and National City Bank specified that all assets of National City Bank were made available for satisfaction of the Petrograd branch's liabilities, Day-Gormley demanded repayment of its deposits from National City Bank's New York branch. ${ }^{156}$ Again, however, Day-Gormley was denied payment. ${ }^{157}$ Day-Gormley then filed suit against National City in New York to recover its deposits.

The Day-Gormley court located situs within Russia because "[a]ll the pertinent transactions between the plaintiff and [National City Bank] took place in Russia."'158 Consequentially, the court applied the act of state doctrine, refusing to invalidate the Soviet government's nationalization and

149. $I d$.

150. $I d$.

151. Id. at 168 .

152. Id. at 169.

153. Day-Gormley Leather Co. v. National City Bank, 8 F.Supp. 503 (1934).

154. Id. at 504

155. $I d$.

156. Id.

157. Id.

158. Id. at 505 . 
confiscation decrees. Unlike the court in Sokoloff, however, the DayGormley court engaged in no temporal interpretation of the decrees and held that National City Bank was not liable to Day-Gormley for the deposit funds. Instead, Day-Gormley could only seek recourse from and rely upon relief provided by the Soviet government. According to the court, "[t]he action of the Soviet government completely destroyed the plaintiff's ownership of the deposit account and remitted the plaintiff solely to such remedy, if any, as was provided by the Soviet government itself under its decrees and regulations on the subject."159

\section{Belmont}

United States $v$. Belmont is yet another case involving bank deposits subjected to Russian nationalization and confiscation decrees. ${ }^{160}$ The Court in Belmont, as in Day-Gormley, engaged in a distinctive analysis to justify application of the act of state doctrine. In Belmont, a Russian corporation named Petrograd Metal Works deposited a sum of money with August Belmont, a private banker operating in New York. ${ }^{161}$ The Soviet government then issued a decree dissolving Petrograd Metal Works and liquidating its assets. ${ }^{162}$ Following a prolonged period of diplomatic negotiation between the United States and the Soviet Union to settle interstate claims, the two states signed the Litinov Assignment. ${ }^{163}$ According to this agreement, "the Soviet government would take no steps to enforce claims against American nationals ... but all such claims were released and assigned to the United States, with the understanding that the Soviet government was to be duly notified of all amounts realized by the United States from such release and assignment."164 The United States then brought suit to recover Petrograd Metal Works' deposits from Belmont in order to transfer the funds to the Soviet Union.

The executors of Belmont's estate resisted United States efforts on the grounds that the Russian decrees, while perhaps valid acts of state with respect to assets located in Russia, did not apply to Belmont's deposits. They contended that the situs of the deposits was the United States, that the funds were not covered by the Russian decree, and were therefore not subject to the Litinov Assignment. The lower court agreed with this situs determination, adopting the view that "the situs of the bank deposit[s] was within the state of New York [and] in no sense could it be regarded as an intangible property right within Soviet territory." 165 However, the Supreme Court reversed this opinion. Citing Underbill and the United States' recent recognition of the Soviet Union, the Court located situs of

159. Id. at 506.

160. United States v. Belmont, 57 S.Ct. 758 (1937).

161. Id.

162. Id.

163. Id. at 759 .

164. Id.

165. Id. 
the debt within Russia and applied the act of state doctrine, validating the seizure of the deposits.

\section{Review of Sokoloff, Day-Gormley, \& Belmont}

In each of these three cases, the courts located situs of the property at issue in Russia, applied the act of state doctrine, and recognized the validity of the Soviet nationalization and confiscation decrees. The courts, however, justified their situs determinations through varied reasoning. The court in Sokoloff relied upon the location of the branch bank in Petrograd to locate situs in Russia. The court in Day-Gormley located situs in Russia because all relevant transactions between the plaintiff and the defendant occurred in Russia. In Belmont, the court relied upon the United States' recognition of the Soviet Union to locate situs in Russia.

These justifications are contradictory and appear contrived when the facts of the cases are considered. For example, the situs determination in Belmont makes little sense in light of the reasoning in Sokoloff fixing situs at the location of the branch bank primarily serving the depositor. Belmont, a private individual, had no branch in Russia. The situs determination in Sokoloff is inexplicable given the reasoning in Day-Gormley that situs of the deposit is where all relevant transactions between the depositor and the bank occur. Sokoloff deposited his funds and formed a depository contract with the New York branch of National City Bank. Moreover, if formal recognition of the Soviet Union automatically implies that the situs of intangible property referenced in Soviet nationalization and confiscation decrees is Russia, then situs in Day-Gormley was wrongly determined. By 1934, when Day-Gormley was decided, the United States had already recognized the Soviet Union.

The comparison of these cases suggests that situs, and the act of state doctrine by implication, is being manipulated to achieve a particular result. The courts' situs determinations serve merely as a mechanism to apply or withhold application of the act of state doctrine on the basis of extrajudicial factors influencing their decisions. Russia was no doubt an illiberal state at the time these cases were decided. According to the liberal internationalist model then, the courts manipulated situs and applied the act of state doctrine on the basis of particular perceived factors. These factors include the awareness of the limitations of judicial competence, the existence of a diplomatic dispute resolution initiative, the position of the Executive, and the judicial belief as to the relative role of the political branches in foreign affairs. It is only by reference to the liberal internationalist understanding of the act of state doctrine that the decisions in these cases maintain coherence.

The lack of a diplomatic dispute resolution initiative, the position of the Executive, and awareness of the limitations of judicial competence primarily influenced the court in Sokoloff. At the outset of the opinion the court noted that "the government of the United States refuses recognition 
of the Soviet Republic as the government of Russia."166 It may be inferred from this that the court was aware that no diplomatic dispute resolution initiative was underway and that the Executive preferred a resolution of the case in a manner that neither suggested the United States' de jure recognition of the Soviet Union nor imperiled the tenuous relations between the United States and the Soviet government. Later in the opinion, the court expressed its limited competence in the matter. According to the court, "[j] uridically, a government that is unrecognized may be viewed as no government at all, if the power withholding recognition chooses thus to view it... [i]n practice, however, since juridical conceptions are seldom, if ever, carried to the limit of their logic, the equivalence is not absolute, but is subject to self-imposed limitations of common sense and fairness... effect may at times be due to the ordinances of foreign governments which, though formally unrecognized, have notoriously an existence as governments de facto." 167

Given the liberal internationalist model's framing of the factors influencing the application of the act of state doctrine, the outcome of Sokoloff is sensible. The court manipulated situs to apply the act of state doctrine to the nationalization and confiscation decrees because invalidating the decrees would upset the already unstable relations between the United States and the Soviet government. In applying the doctrine, however, the court was careful to specify that it regarded the Soviet government as merely the de facto, not de jure, government of the Russian state, thereby respecting Executive authority over sovereign recognition. Yet, because a straightforward application of the doctrine would likely drive the plaintiffs to directly petition the unrecognized Soviet government for compensation, the court creatively interpreted the nationalization and confiscation decrees to avoid the unpredictable consequences of this occurrence.

The court's opinion in Day-Gormley may also be explained by reference to the liberal internationalist model's factors. The court began by noting the Executive's ex post expression of consent to the validity of the nationalization and confiscation decrees, stating that "[s]ubsequent to the attempted or purported confiscation[,] the government of the United States granted full diplomatic recognition to that revolutionary government."168 The court then outlined its understanding of the limits of its competence and of the formative role of the political branches in foreign affairs. According to the court, "regardless of how [it] may feel as to what are the equities as between the parties... [for it] to employ to any other end the judicial power with which it is vested would, as [it] conceive[s], be a trespass upon the functions of the political branch of the government of the United States." 169 In other words, the court opted to

166. Sokoloff, 239 N.Y. at 163-64.

167. Id. at 165.

168. Day-Gormley, 8 F.Supp. at 505.

169. Id. at 506 . 
apply the act of state doctrine in deference to the Executive's expression of consent because it understood that the Executive is better equipped and more empowered to act in matters concerning foreign affairs.

In Belmont, the position of the Executive, the Court's understanding of the relative role of the political branches in foreign affairs, and the existence of a diplomatic dispute resolution initiative explain the outcome. After taking "judicial notice of the fact that... the President recognized the Soviet government, and normal diplomatic relations were established between that government and the government of the United States[,]" the Court expressed its understanding of the relative role of the political branches in foreign affairs. It stated that "the Executive had authority to speak as the sole organ of [the United States]"170 and cited approvingly remarks of an English judge that courts should not "come to the conclusion that the legislation of a state recognized ... as an independent sovereign state is so contrary to moral principle that the judges ought not to recognize it.. [t] he responsibility for recognition or non-recognition with the consequences of each rests on the political advisers of the Sovereign and not on the judges." 171 The Court then referred to the controlling influence of the Litinov Assignment on its adjudication of the dispute. According to the Court, the Litinov Assignment "result[ed] in an international compact between the two governments... [and] [t] hat the negotiations, acceptance of the assignment, and agreements and understandings in respect thereof were within the competence of the President may not be doubted." 172 Given the Court's understanding of its limited role in foreign affairs and the position of the Executive as expressed in the Litinov Assignment, the Court manipulated situs, locating it in Russia, and applied the act of state doctrine.

\section{CONCLUDING REMARKS}

Increased attention to international relations theory may greatly enhance the development and synthesis of international law. International relations theory places international law in a broader context and expands the scope of analysis, permitting more expansive inquiry into the merits and coherence of international legal doctrines. As this paper has aspired to demonstrate, liberal international relations theory, with its focus on the relationship between states' domestic structures and their international behavior, is particularly useful in examining the efficacy of transnational legal doctrines such as the act of state doctrine.

Legal scholars' traditional attempts to interpret judicial application of the act of state doctrine have failed. These scholars, examining the doctrine strictly within the confines of the legal tradition, have yet to agree upon the foundations and proper use of the doctrine. Revisionist efforts

170. Belmont, 57 S.Ct. at 761 .

171. Id. at 760 .

172. Id. 
to synthesize judicial application of the doctrine are also without merit. These efforts do little to improve the traditional interpretations of the doctrine. Because the act of state doctrine is a legal doctrine with foreign affairs implications, it is only by reference to international relations theory, namely liberalism, that the doctrine may be properly understood.

The liberal internationalist model posits that transnational legal relations between liberal-liberal and liberal-illiberal dyads will differ because liberal and illiberal states operate pursuant to entirely different ordering principles. These differences impact the ability of courts in liberal states to recognize legitimate difference with other states. Courts examining acts of liberal states are more likely to engage in a form of reciprocal dialogue with these states, whereas courts examining acts of illiberal states are more likely to look to the political branches for guidance. Act of state jurisprudence must therefore be bifurcated into cases involving liberal states and cases involving illiberal states to be properly understood. According to the liberal internationalist model, judges apply the act of state doctrine in cases involving liberal and illiberal states on the basis of particular factors relevant to transnational legal relations. For example, in cases involving illiberal states, the court's awareness of the limitations of its competence, the existence of a diplomatic dispute resolution initiative, the position of the Executive, and the court's belief as to the relative role of political branches in foreign affairs influence judicial application of the doctrine.

As a first step toward demonstrating the efficacy of the liberal internationalist model's explanation of the act of state doctrine, this paper examined three cases involving nationalization and confiscation decrees issued following the Russian Revolution. In each case, the court manipulated situs and applied the act of state doctrine consistent with the liberal internationalist model's predictions. Admittedly, these cases represent only a small subset of cases that must be analyzed to conclusively demonstrate the liberal internationalist model's validity. Further confirmation of the liberal internationalist model's interpretation of the act of state doctrine must be pursued and may spur its revision or reformulation. Cases involving Russia arising out of different facts, cases involving other illiberal states, and cases involving liberal states must be thoroughly examined. Yet, regardless of the outcome of this effort, the preliminary analysis of these cases demonstrates the value of increased incorporation of international relations theory into international legal scholarship. Perhaps, over time, the students of law and students of politics will increasingly heed Professor Henkin's words, recognize the benefits of cross-disciplinary discourse, and converse with one another.

Word Count: 11,094 